\title{
IDENTIFICATION OF HAPLOID MAIZE BY FLOW CYTOMETRY, MORPHOLOGICAL AND MOLECULAR MARKERS
}

\author{
Identificação de milho haploide por citometria de fluxo, \\ marcadores morfológicos e moleculares
}

\author{
Evellyn Giselly de Oliveira Couto ${ }^{1}$, Livia Maria Chamma Davide ${ }^{2}$, \\ Fernanda de Oliveira Bustamante ${ }^{3}$, Renzo Garcia Von Pinho ${ }^{4}$, Tallyta Nayara Silva ${ }^{5}$
}

\begin{abstract}
The development of homozygous breeding lines in maize may be accelerated through the use of haploids. Thus, the obtaining and prior identification of haploids generated by the haploid inducer lines is an important factor. The purpose of this study was to identify haploids by flow cytometry and to correlate the nuclear DNA content to the morphological and morphometric traits of the seeds that gave rise to them. In addition, molecular markers were used to confirm the androgenetic nature of the haploid. The seeds obtained were derived from the cross between the inbred line W23 and the commercial hybrid P30F90. Among these seeds, a group was selected, putative haploids, whose embryo was white and the pericarp purplish. This group, consisting of 330 seeds, was characterized based on seed morphology, seed morphometry and nuclear DNA content. Flow cytometry analyses identified four haploids, and all of them were small size plants and had brittle leaves. The weight, length, thickness and width of the haploid seeds were very variable indicating that morphometric traits do not constitute reliable data for visual selection of haploid seeds. Based on results, the inbred line W23 induced haploid maize even under tropical conditions. Microsatellite molecular markers (SSR) proved to be efficient, confirming the androgenetic trait of the haploids.
\end{abstract}

Index terms: Zea mays, nuclear DNA content, androgenetic inheritance, R-navajo, microsatellites.

\section{RESUMO}

O desenvolvimento de linhagens homozigotas em milho pode ser acelerado por meio do uso de haploides. Para isso, a obtenção e identificação prévia dos haploides gerados pelas linhagens indutoras de haploidia é um fator importante. O objetivo do trabalho foi identificar haplóides por meio de citometria de fluxo para então correlacionar o conteúdo de DNA nuclear aos caracteres morfológicos e morfométricos das sementes que os originaram. Além disso, marcadores moleculares foram utilizados para confirmar a natureza androgenética do haploide. As sementes obtidas foram provenientes do cruzamento entre a linhagem W23 e o híbrido comercial P30F90. Dentre essas sementes, foi selecionado um grupo, possíveis haplóides, cujo embrião era branco e o pericarpo arroxeado. Esse grupo, constituído de 330 sementes, foi caracterizado quanto à morfologia, morfometria e conteúdo de DNA nuclear. As análises de citometria de fluxo identificaram quatro haploides, e todos eles apresentaram porte reduzido e folhas quebradiças. Os pesos, comprimentos, espessuras e larguras das sementes haplóides variaram muito, indicando que caracteres morfométricos não são eficientes para a seleção visual de haploides. Baseado nos resultados, a linhagem W23 induz haplóides em milho mesmo em condições tropicais. Os marcadores moleculares microssatélites (SSR) mostraram-se eficientes, comprovando o caráter androgenético dos haploides.

Termos para indexação: Zea mays, conteúdo de DNA nuclear, herança androgenética, R-navajo, microssatélites.

(Received in october 16, 2012 and approved in december 12, 2012)

\section{INTRODUCTION}

Haploid induction in maize (Zea mays) has allowed great advances in breeding of this crop. Doubled-haploid (DH) lines are routinely used in many companies that sell hybrid maize. This technology has been used because it provides some advantages, such as: possibility of homozygosis in only one generation; enrichment of the genetic pool of favorable genes, or elimination of unfavorable genes; and capability of providing a broad source of material for genetic mutations (DANG et al., 2011).

In breeding programs with doubled haploids, fast and precise identification of the haploids is very important. The most used marker is based on antocyanine pigmentation, which is generated by a dominant allele of

\footnotetext{
'Universidade Federal de Lavras/UFLA - 37.200-000 - Lavras - MG - Brasil - evellyn.couto@yahoo.com.br

2Universidade Federal da Grande Dourados/UFGD - Brasil

3Universidade Federal de Lavras/UFLA - Lavras - MG - Brasil

${ }^{4}$ Universidade Federal de Lavras/UFLA - Departamento de Agricultura/DAG - Lavras - MG - Brasil

Enniversidade Estadual Paulista/UNESP - Jaboticabal - SP - Brasil
} 
the R-navajo system (R1-nj). Nanda and Chase (1966) were the first to use coloring from aleurone in selection of haploid seeds. This allele promotes antocyanine pigmentation in the endosperm and in the embryo of the diploid seeds - the haploid seeds show pigmentation only in the endosperm, with the embryo remaining white. Nevertheless, the marker allele $R I-n j$ has variable expressiveness, not providing a precise indication of the haploid seeds (GEIGER; GORDILLO, 2010), and thus it is important to associate the marker with other methods, such as morphological and molecular traits, at the time of selection of the putative haploids.

In haploid induction, the use of specific breeding lines, which has been known as inducers, is important in the crosses. Two models for in vivo induction of haploids may be distinguished in maize, the gymnogenetic and androgenetic systems. Currently, most of the inducer lines in maize are derived from two temperate lines: Stock 6, which generates gymnogenetics (COE, 1959); and Wisconsin 23 (W23), which generates androgenetic haploids (KERMICLE, 1969). In the case of induction of the androgenetic haploid, the pollenizer will serve as the genome donor and the female as inducer (KERMICLE, 1969). The opposite occurs in gynmogenetic induction.

Haploid plants have been screened from diploids from diverse ways. In the field, they are generally of reduced size due to the volume of their cells. In addition to this characteristic, ploidy may be confirmed by other methods, such as: flow cytometry (BARRET; BRINKAMANN; BECKERT, 2008; DANG et al., 2011; CHOE et al., 2012), molecular markers (BELICUAS et al., 2007; DIAO et al., 2009) and isoenzymes (LIU; DOUCHES, 1993; MARKOVA, 2001).

The purpose of this study was to a) characterize using morphological and morphometric traits the putative haploids derived from crossing of the inbred line W23 with the commercial hybrid P30F90; b) detect haploids by flow cytometry technique and to correlate the haploid trait to the morphological and morphometric traits of the seeds; and c) confirm the androgenetic nature of the haploids by SSR molecular markers.

\section{MATERIAL AND METHODS}

The research was conducted in the laboratories and experimental area of the Department of Agriculture of the Universidade Federal de Lavras. To conduct the experiment, the hybrid P30F90 was crossed with the inducer line W23 (used as female parent). In this study, we deal with androgenetic induction of haploids. The seeds obtained were separated, numbered and individually morphological and morphometrical characterized. The group of putative haploids (white embryo and endosperm purplish spot) was selected and its seeds were classified in regard to position and size of the spots. In addition, the seeds were characterized based on weight (g) and morphometric traits (length, width and thickness in mm). After this stage, the seeds were placed for germination.

Nuclear DNA content measurement, using flow cytometry, was obtained from leaves of the parents and the 330 descendants. For each sample, approximately 20$30 \mathrm{mg}$ of young leaves was used together with the same quantity of Vicia faba L. (internal reference standard, 2C $=26.9$ picograms, pg) (DOLEZEL; SGORBATI; LUCRETTI, 1992). The samples were ground into a Petri dish containing $1 \mathrm{~mL}$ of cold buffer LB01 so as to obtain the nuclear suspension (DOLEZEL, 1997), to which was added 2.5i $\mathrm{i}$ of RNase and stained with $25 \mu \mathrm{L}$ of propidium iodide $\left(1 \mathrm{mg} \mathrm{mL}^{-1}\right)$. For each sample at least 10,000 nuclei were analyzed. The histograms were obtained in the cytometer FacsCalibur (Becton Dickinson) with the Cell Quest program (Becton, Dickinson and Company, San Jose, CA, USA) and analyzed on the software WinMDI $2.8(2009)$.

The haploid plantlets confirmed by flow cytometry were monitored in their growth and development in the field, with the morphological differences being observed visually.

For molecular analyses, leaf samples from six individuals, grown in the field, were collected: from the parents, individual haploids 250 and 485 and individual diploids 141, 143. Both haploid and diploid materials were previously identified by flow cytometry. DNA extraction procedure was performed according to Pereira et al. (2007). The amplification products were submitted to vertical electrophoresis for 2 hours and fifteen minutes at $125 \mathrm{~V}$ in polyacrylamide gel $6 \%$ stained in silver nitrate and photographed with a digital camera. After verification of the polymorphism in the parents, two primers considered polymorphic (BNLG2305 and UMC1227) were used in the progenies to verify the androgenetic nature of the haploids.

\section{RESULTS AND DISCUSSION}

From the cross between the inducer line $\mathrm{W} 23$ and the hybrid P30F90, 1429 seeds were obtained, of which 397 were selected as the putative haploid seeds. These seeds were classified in regard to the size of the spots on the pericarp (Figure 1). 

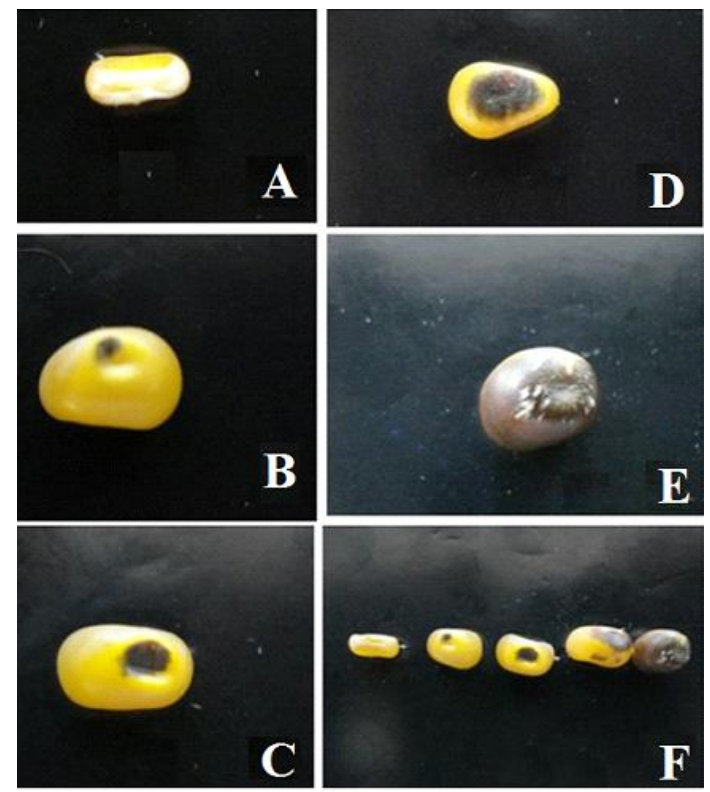

Figure 1 - Level of spotting caused by expression of the $\mathrm{R}$ - navajo gene, ordered in regard to size - A) Absence of expression; B, C and D) Increasing levels of expression; E) Total expression of the gene in the seed; F) Comparison of all the levels of expression of R-navajo.

Of the 397 seedlings transplanted, 60 did not germinate and 7 died in the field. From 330 plants, four haploids were screened by the flow cytometry technique. The haploid plants found correspond to the individuals 233, 240, 250 and 485.

The mean values of DNA content, in pg, and the coefficient of variation (CV) related to G0/G1 peak of the parents, haploids and diploid hybrids is summarized in table 1. The representative histograms obtained from these plants are represented in figure 2 .

Table 1 - Mean values of nuclear DNA content and CV of the parents (W23 and P30F90), haploids and diploid hybrids.

\begin{tabular}{ccc}
\hline Individuals & Mean nuclear DNA content & CV $(\%)$ \\
\hline W23 & 5.63 & 0.52 \\
P30F90 & 6.24 & 0.69 \\
Haploids & 2.83 & 0.74 \\
Diploids & 5.77 & 1.61 \\
\hline
\end{tabular}

Considering the 1429 seeds, approximately $27.8 \%$ were visually classified as haploids according to the expression of the R- $n j$ allele. Nevertheless, the frequency of haploidy detected by flow cytometry was only $0.28 \%$. This value is less than that suggested by Kermicle (1969), who described that the inbred line W23 generates androgenetic haploids at a rate varying from 1 to $3 \%$. This low induction value may have been caused by use of a temperate inducer under tropical conditions, and by the type of endosperm of the parent. This result suggests the need for tropicalization of haploidy inducer lines (PRIGGE, et al., 2011), as well as the need for identifying new markers in haploid selection. Thus, in spite of the low percentage, the induction of haploids in the cross between W23 and P30F90 was successful, which proves that the line has potential for generating androgenetic haploids under tropical conditions. However, it is not efficient for use in plant breeding programs.

Flow cytometry has been used in studies related to doubled haploids due to its accuracy, quickly and reliability in identifying them. Dang et al. (2011) used this tool to detect false positives in bulks of maize seeds. Other authors have used this technique in other species, especially in in vitro cultures (LATADO et al., 2007; MOHAMMADI; MOIENI; JALALI-JAVARAN, 2007; PINTOS et al., 2007; PRAÇA; CARVALHO; CLARINDO, 2009; KAENSAKSIRI et al., 2011; CARDOSO; MARTINELLI; LATADO, 2012; HE et al., 2012; KLEIBER et al., 2012; MOHAMMADI et al., 2012).

Based on the results obtained by flow cytometry, it was possible to correlate the characteristics of the seeds classified by weight, morphometric traits and presence of the $R 1-n j$ gene with the haploid trait (Table 2).

Morphometric characteristics, weights, lengths, thicknesses and widths of the haploids seeds, are not reliable data for visual selection of the putative haploids considering their great variation (Figure 3 ). Based on the results, it might be observed that the coloring of the pericarp with antocyanine is a trait of incomplete penetrance and variable expressiveness and probably does not provide a precise indication of the haploid seeds. The results were corroborated by those obtained for Belicuas et al. (2007).

In addition, the mean values of the weights and morphometric traits of the diploid hybrid seeds and haploids confirmed by flow cytometry show approximate values (Table 3 ), indicating once more that morphometric traits do not constitute reliable data in selection of haploid seeds. It may also be seen that haploid seeds are practically the same size as diploid seeds, and it is difficult to differentiate them at the time of selection. 

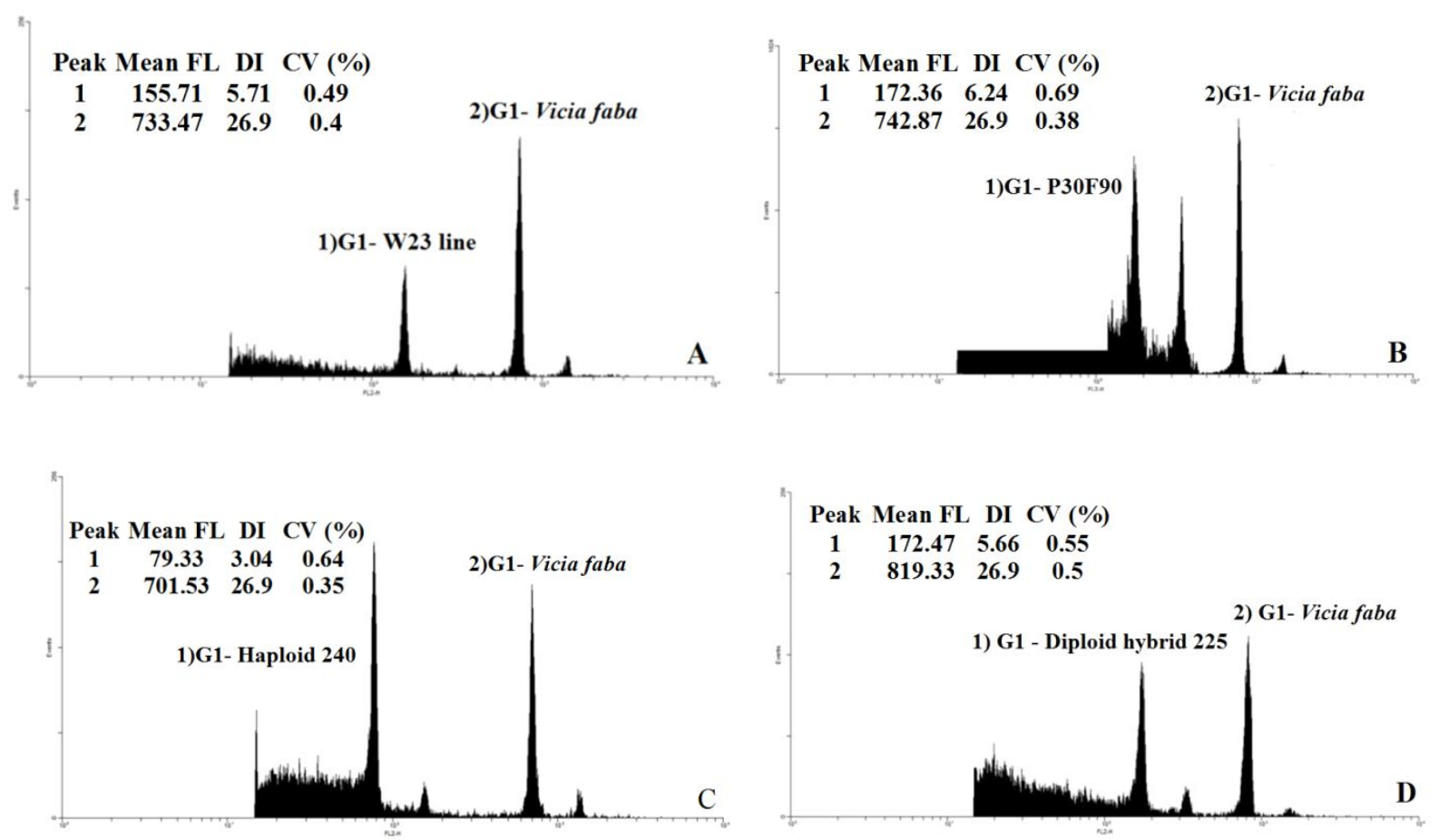

Figure 2 - Flow cytometric histograms of relative fluorescence obtained after simultaneous analysis of nuclei isolated from the internal reference standard (Vicia faba) with $2 \mathrm{C}=26.9 \mathrm{pg}$ DNA and maize: A) Parent W23, with 5.71 pg DNA. B) Parent P30F90 (commercial hybrid) with 6.24 pg DNA . C) Haploid 240 with 3.04 pg DNA . D) Diploid hybrid 225 with $5.66 \mathrm{pg}$ DNA. The mean channel number (mean FL), DNA index (DI = mean channel number of sample / mean channel number of reference standard) and coefficient of variation value $(\mathrm{CV}, \%)$ of each peak are also given. Vertical axis $=$ number of nuclei read; horizontal axis = intensity of relative fluorescence.

Table 2 - Morphological characteristics of the seeds that gave rise to haploids.

\begin{tabular}{cccccc}
\hline $\begin{array}{c}\text { No. of haploid } \\
\text { seeds }\end{array}$ & $\begin{array}{c}\text { Weight } \\
(\mathrm{g})\end{array}$ & $\begin{array}{c}\text { Length } \\
(\mathrm{mm})\end{array}$ & $\begin{array}{c}\text { Width } \\
(\mathrm{mm})\end{array}$ & $\begin{array}{c}\text { Thickness } \\
(\mathrm{mm})\end{array}$ & Expression of the $R 1-n j$ \\
\hline 233 & 0.128 & 7.74 & 5.5 & 4.67 & Spot on the apex of the seed \\
240 & 0.203 & 9.27 & 6.33 & 5.26 & Spot on the apex of the seed \\
250 & 0.219 & 7.44 & 6.73 & 6.45 & Spot on the apex of the seed \\
485 & 0.12 & 8.16 & 5.02 & 5.7 & Spot on the entire apex of the seed \\
\hline
\end{tabular}

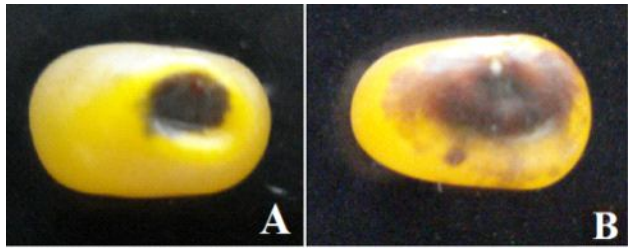

Figure 3 - Spots resulting from expression of the $R 1-n j$ gene on the seeds derived from the cross between W23 and P30F90 and found on haploid seeds. A) Spot on the apex of the seed; B) Spot on the entire apex of the seed.
All four plants identified as haploids had small size, absence of ligula, presence of fragile and brittle leaves, and had a different leaf arrangement (Figure 4) when compared to an individual diploid. Nevertheless, it was observed that various plants considered diploids by flow cytometry are also of small size (BELICUAS et al., 2007).

The SSR molecular marker was performed to confirm the androgenetic trait of the haploid. SSR markers have been widely used in research involving ploidy and chromosome duplication (BARRET; BRINKAMANN; BECKERT, 2008; 
BELICUAS et al., 2007; PERERA et al., 2008; DIAO et al., 2009; ZHANG et al., 2008; LI et al., 2009; MAYOR; BERNARDO, 2009; KEBEDEetal., 2011; PRIGGEetal., 2012).

The androgenetic trait of the haploids was confirmed by the SSR molecular markers since they have only one band, which coincides with the band of the commercial hybrid P30F90 (pollen donor), while the diploid individuals have two bands, each one corresponding to the allele of each parent (Figure 5).
The results obtained are once more corrobated by those presented by Belicuas et al. (2007), who identified four haploids among 462 plants obtained from the cross between the line W23 and the hybrid BRS1010. Two polymorphic primers were used on the parents, mmc0022 and mmc0081. The four haploids have have the same size bands as the male parent; in other words, they were characterized as androgenetic haploids.

Table 3 - Morphometric means of the hybrid seeds, putative haploids and haploids confirmed by flow cytometry.

\begin{tabular}{lcccc}
\hline Individuals & $\begin{array}{c}\text { Weight } \\
(\mathrm{g})\end{array}$ & $\begin{array}{c}\text { Length } \\
(\mathrm{mm})\end{array}$ & $\begin{array}{c}\text { Width } \\
(\mathrm{mm})\end{array}$ & $\begin{array}{c}\text { Thickness } \\
(\mathrm{mm})\end{array}$ \\
\hline Diploid hybrids & 0.17 & 8.05 & 6.71 & 5.04 \\
Putative haploids & 0.17 & 8.12 & 6.59 & 5.26 \\
Haploids & 0.18 & 8.15 & 5.89 & 5.52 \\
\hline
\end{tabular}

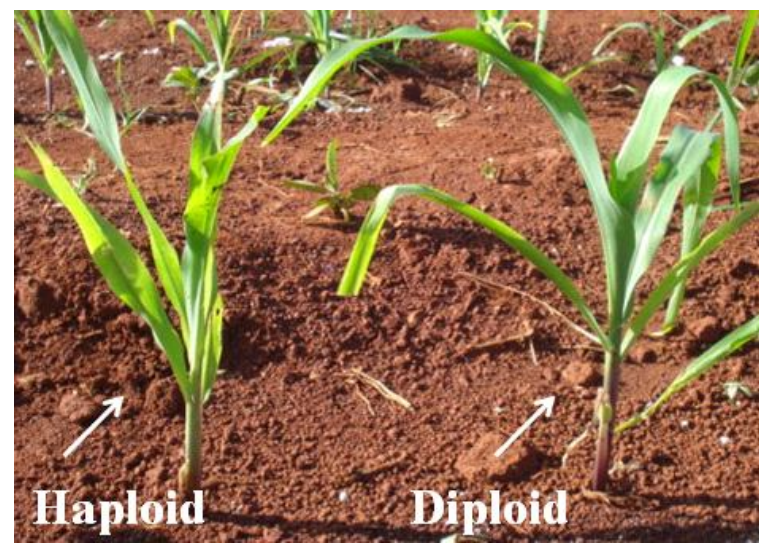

Figure 4 - Differences in leaf arrangement of haploid and diploid individuals.
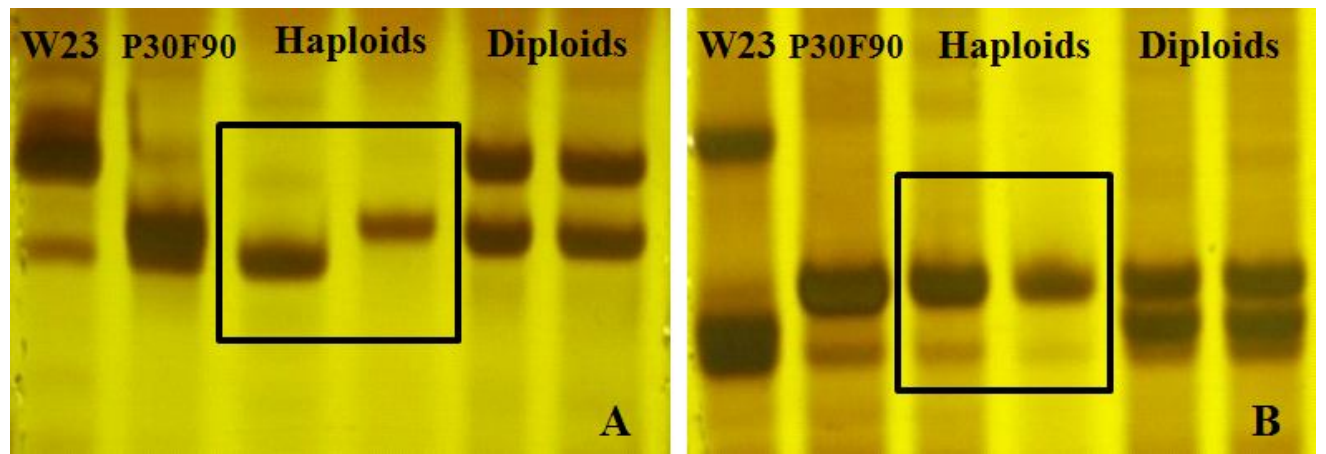

Figure 5 - Electrophoretic pattern of the amplification products of the polymorphic primers in the parents (W23 and P30F90), haploids (250 and 485) and hybrids (143 and 144). A) Primer BNLG2305; B) Primer UMC1227. The rectangle delimits the haploids, showing the androgenetic trait. 


\section{CONCLUSIONS}

The W23 line generates haploids even under tropical conditions when the P30F90 genotype is used as male parent.

Morphometric and morphological traits are not reliable for identification of haploid individuals.

The phenotypic marker system based on the R- $n j$ allele was not reliable for haploid selection.

The SSR molecular markers were efficient in confirmation of the androgenetic trait of the W23 line.

\section{ACKNOWLEDGMENTS}

To the Fundação de Amparo à Pesquisa do Estado de Minas Gerais and to the Conselho Nacional de Desenvolvimento Científico e Tecnológico, for financial support.

\section{REFERENCES}

BARRET, P.; BRINKAMANN, M.; BECKERT, M. A major locus expressed in the male gametophyte with incomplete penetrance is responsible for in situ gynogenesis in maize. Theoretical and Applied Genetics, Clermont-Ferrand, v.117, n.4, May, p.581594, 2008.

BELICUAS, P.R. et al. Androgenetic haploids and SSR markers as tools for the development of tropical maize hybrids. Euphytica, Wageningen, v.156, n.1, Feb., p.95102, 2007.

\section{CARDOSO, J.C.; MARTINELLI, A.P.; LATADO, R.R.}

Somatic embryogenesis from ovaries of sweet orange cv. Tobias. Plant Cell, Tissue and Organ Culture, Amsterdam, v.109, n.1, Oct., p.171-177, 2012.

CHOE, E. et al. Improving in vivo maize doubled haploid production efficiency through early detection of false positives. Plant Breeding, Bonn, v.131, n.1, Feb., p.399401, 2012.

COE, E. H. A line of maize with high haploid frequency. American Naturalist, Chicago, v.93, n.870, Jun., p.381$382,1959$.

DANG, N-C. et al. Inducer line generated double haploid seeds for combined waxy and opaque 2 grain quality subtropical maize (Zea mays. L.). Euphytica, Zurich, v.183, n.3, Apr., p.153-160, 2011.
DIAO, W.P. et al. Efficient embryo induction in cucumber ovary culture and homozygous identification of the regenerants using SSR markers. Scientia Horticulturae, Mission, v.119, n.4, Feb., p.246-251, 2009.

DOLEZEL, J.; SGORBATI, S. e LUCRETTI, S. 1992. Comparison of three DNA fluorochromes for flow cytometry estimation of nuclear DNA content in plants. Physiologia Plantarum, Umea, v.85, n.4, Aug., p.625631, 1992.

DOLEZEL, J. Application of flow citometry for the study of plants genomes. Journal of Applied Genetics, Olomouc, v.38, n.3, Jun., p.285-302, 1997.

GEIGER, H.H.; GORDILLO, G.A. Double haploids in hybrid maize breeding. Maydica, Bergamo, v.54, n.1, Jan., p.485-499, 2010.

HE, L.Y. et al. Induction and identification of hexadecaploid of Pinellia ternate. Euphytica, Wageningin, Province, v. 186, n.3, Mar., p.479- 488, 2012.

KAENSAKSIRI, T. et al. In vitro induction of polyploidy in Centella asiatica (L.) Urban. Plant Cell Tissue and Organ Culture, Bangkok, v.107, n.1, May., p.187-194, 2011.

KEBEDE, A.Z. et al. Effect of source germplasm and season on the in vivo haploid induction rate in tropical maize. Euphytica, Wageningin, v.180, n.1, Feb., p.219-226, 2011.

KERMICLE, J.L. Androgenesis conditioned by a mutation in maize. Science, Washington D. C, v.166, n.3911, Dec., p.1422-1424, 1969.

KLEIBER, D. et al. Haploid fertility in temperate and tropical maize germplasm. Crop Science, Madison, v.52, n.2, Mar./Apr., p.623-630, 2012.

LATADO, R.R. et al. Plantas autotetraplóides de citros sob tratamento in vitro com colchicina. Pesquisa Agropecuária Brasileira, Brasília, v.42, n.10, Out., p.1429-1435, 2007.

LI, L. et al. Morphological and molecular evidences for DNA introgression in haploid induction via a high oil inducer CAUHOI in maize. Planta, Beijing, v.230, n.2, May., p.367-376, 2009. 
LIU, C.A.; DOUCHES, D.S. Production of haploids of potato (Solanum tuberosum subsp. tuberosum) and their identification with electrophoretic analysis.

Euphytica, Wageningen, v.70, n.3, Aug., p.113-126, 1993.

MARKOVA, M. et al. Application of esterase patterns for identification of the type of haploidy in F1 hybrids in maize. Bulgarian Academy of Sciences, Bulgarian, v.54, n.9, May., p.83-86, 2001.

MAYOR, P.J.; BERNARDO, R. Doubled haploids in commercial maize breeding: one- stage and two- stage phenotypic selection versus marker- assisted recurrent selection. Maydica, Bergamo, v.54, n.3, Nov., p.439-448, 2009.

MOHAMMADI, P.P; MOIENI, A.; JALALI-JAVARAN, M. Colchicine induced embryogenesis and doubled haploid production in maize (Zea mays L.) anther culture. Iranian Journal of Biotechnology, Tehran, v.5, n.3, Jul., p.140-146, 2007.

MOHAMMADI, P.P. et al. Doubled haploid plants following colchicine treatment of microspore-derived embryos of oilseed rape (Brassica napus L.) Plant Cell Tissue and Organ Culture, Tehran, v.108, n.3, Oct., p.251-256, 2012.

NANDA, D.K; CHASE, S.S. An embryo marker for detecting monoploids of maize (Zea mays L.) Crop Science, Madison, v.6, n.2, Mar./Apr., p.213-215, 1966.

PEREIRA, H.S. et al. Informações fenotípicas e marcadores microssatélites de QTL na escolha de populações segregantes de feijoeiro. Pesquisa Agropecurária Brasileira, Brasília, v.42, n.4, May., p.707-713, 2007.

PERERA, P.I.P. et al. Use of SSR markers to determine the anther-derived homozygous lines in coconut. Plant Cell Report, Lunuwila, v.27, n.2, Aug., p.1697-1703, 2008.

PINTOS, B.; MANZANERA, J. A.; BUENO, M. A. Antimitotic agents increase the production of doubledhaploid embryos from cork oak anther culture. Journal of Plant Physiology, Madrid, v.164, n.11, Nov., p.15951604, 2007.

PRAÇA, M. M.; CARVALHO, C. R.; CLARINDO, W. R. A practical and reliable procedure for in vitro induction of tetraploid tomato. Scientia Horticulturae, Viçosa, v.122, n.3, May., p.501-505, 2009.

PRIGGE, V. et al. Doubled haploids in tropical maize: I. Effects of inducers and source germplasm on in vivo haploid induction rates. Crop Science, Madison, v.51, n.5, Aug., p.1498- 1506, 2011.

PRIGGE, V. et al. Doubled haploids in tropical maize: II. Quantitative genetic parameters for testcross performance. Euphytica, Wageningen, v.185, n.3, Jan., p.453-463, 2012.

ZHANG, Z. et al. Chromosome elimination and in vivo haploid production induced by Stock 6-derived inducer line in maize (Zea mays L.). Plant Cell Reports, Heidelberg, v.27, n.12, Dec., p.1851-1860, 2008. 